Research Article

\title{
A Study of Fresh Fruit Juice of (Hybrid Perentage)- Malus domestica X M. Sylvestris against Experimentally Induced Alzheimer's Disease in Mice
}

\author{
Vineetha M, Aniruddha Banerjee, Karunakar Hegde* \\ Department of Pharmacology, Srinivas College of Pharmacy Mangalore, Karnataka, India \\ *Corresponding author's E-mail: khegde_sh2003@yahoo.co.in
}

Received: 03-01-2021; Revised: 22-02-2021; Accepted: 28-02-2021; Published on: 20-03-2021.

\section{ABSTRACT}

This study was designed to evaluate fresh fruit juice of (HYBRID PERENTAGE)-malus domestica $x$ M.sylvestris(FFJMDXMS) for Alzheimer's disease in mice. The cognitive enhancing activity of fruit juice on scopolamine induced memory impairment in mice was investigated by using behavioural parameter viz, Morris water maze (MWM), Passive shock avoidance paradigm (PSAP) and estimation of biochemical parameter in terms of AchE activity. Two doses $(1 \mathrm{ml} / \mathrm{kg})$ and $(1.5 \mathrm{ml} / \mathrm{kg}, \mathrm{b} . \mathrm{w}$, p.o) of juice were subjected for the study against experimentally induced Alzheimer's disease in mice using scopolamine $(0.4 \mathrm{mg} / \mathrm{kg}$, i.p). Piracetam $(400 \mathrm{mg} / \mathrm{kg}$, i.p) was served as standard in both the models. The long term administration of both the low $(1 \mathrm{ml} / \mathrm{kg})$ and high dose $(1.5 \mathrm{ml} / \mathrm{kg})$ of juice produced significant reduction of transfer latency $(T L)$ and escape latency time $(E L T)(P<0.01)$ and $(P<0.05)$ in PSAP and MWM respectively. An increase of time spent in target quadrant (TSTQ) value in MWM model on both $19^{\text {th }}$ and $27^{\text {th }}$ day when compared to control and induced groups was observed. The fruit juice at higher dose significantly $(p<0.01)$ reduced the activity of AchE in the brain indicates the improvement in learning and retention of memory in young mice. From the above data it is concluded that fresh fruit juice of (HYBRID PERENTAGE)-malus domestica $x$ M.sylvestris was found to be effective against amnesia induced by scopolamine in experimentally in Alzheimer's mice.

Keywords: Morris water maze, Nootropic, Passive shock avoidance paradigm, Scoplolamine

QUICK RESPONSE CODE $\rightarrow$

DOI:

10.47583/ijpsrr.2021.v67i01.002

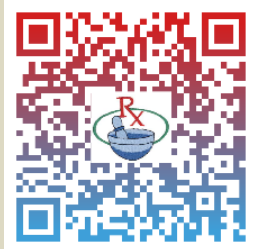

DOI link: http://dx.doi.org/10.47583/ijpsrr.2021.v67i01.002

\section{INTRODUCTION}

ging of the brain is a continuous linear process that begins at conception. Two third of the people eventually experience some significant loss of mental lucidity and independence as a result of aging. People aged 60 years and older experience significant cognitive decline, including declines in memory, concentration, clarity of thought, focus and judgement with an increase in the onset of several neurological problems. ${ }^{1}$ Nootropics are the cognitive enhancers or nutraceuticals that are purported to improve mental functions, such as cognition, memory, intelligence, motivation and concentration, are also used for mental and learning deficit in children. Typically, nootropics are alleged to work by increasing the levels of neurochemicals in the brain. ${ }^{2}$

Alzheimer's disease (AD) is the most common form of dementia considered as progressive, neurodegenerative disease characterized by the presence of senile plaques rich in insoluble aggregate of beta-amyloid and neurofibrillary tangles in the brain. ${ }^{3}$ Currently, 30 million people are affected worldwide by dementia with 4.6 million cases annually as per AD International analysis. ${ }^{4}$ Factors such as decreased acetylcholine level, oxidative stress, and hypercholesterolemia have been reported in memory decline. ${ }^{5}$ Many acetylcholinesterase inhibitor drugs are available in the market to treat, but they have modest benefits and associated with side effects; hence, different drugs are aiming at diverse targets which are expected to act better than single targeting agents to treat AD. ${ }^{6}$ Donepezil, a reversible non-competitive cholinesterase enzyme inhibitor considered as first-line treatment in AD. ${ }^{7}$ Acetylcholine is a neurotransmitter that plays a key role in cognitive function and reasoning. The brains of those with mild-to-moderate Alzheimer's disease, a progressive type of dementia, have abnormally low acetylcholine concentrations. This means that any compound that enhances the cholinergic system in the brain may be useful in treating Alzheimer's disease and similar brain malfunctions.

(HYBRID PERENTAGE)-malus domestica X M.sylvestris (Green apple) is one of the most important fruit belongs to the family Rosaceae. The tree is thought to be a hybrid of Malus sylvestris, the European wild apple, with the North American apple Malus domestica as the polleniser. The fruit is hard, with a light green skin and crisp, juicy flesh. The flavors is tart and acidic, which possibly limits raw consumption. ${ }^{8}$ Apples are a widely consumed, rich source of phytochemicals, and epidemiological studies have linked the consumption of apples with reduced risk of some cancers, cardiovascular disease, asthma, and diabetes. In the laboratory, apples have been found to have very strong antioxidant activity, inhibit cancer cell 
proliferation, decrease lipid oxidation, and lower cholesterol. Apples contain a variety of phytochemicals, including quercetin, catechin, phloridzin and chlorogenic acid, all of which are strong antioxidants. ${ }^{9}$

The aim of the research is to find out new nootropic drugs from fruits which are potent and nontoxic agents. Normally herbal plants and fruits products are free from side effects or adverse effects and they are low-cost medicines which will be beneficial for the people. The present study of fresh fruit juice of green apple will satisfy for better and cost-effective neuroprotective treatment.

\section{MATERIALS AND METHODS}

\section{Collection and authentication of fruit material}

The fresh fruits of Green delicious apples used for the present studies were collected from Mangalore supermarket in November 2018 and was authenticated by Botanist.

\section{Extraction}

Fresh whole apple (Green apple) fruits weighing about 180-200g will be used. Each Green apple fruit will be washed and chopped into small sizes before it will be blended with the aid of electric blender. The fresh fruit juice (golden-coloration) will be extracted by gravity-aided filtration using a clean white cotton cloth. This process of extraction will be done on a daily basis because the juice often oxidizes quickly, with notable change in color. ${ }^{10}$

\section{Dose selection}

Doses were selected according to the earlier research work carried on. Two doses were selected and was administered post orally at a constant volume of $1 \mathrm{ml} / \mathrm{kg}$ (low dose) and $1.5 \mathrm{ml} / \mathrm{kg}$ (high dose) for each animals. ${ }^{10}$

\section{Phytochemical evaluation ${ }^{10}$}

The principle bioactive components of green apple are polyphenols, vitamin B, C, flavonoids like quercetin, epicatechin, catechin and procyanidin. Quercetin is a natural pigment present in green apple, were found to have the strongest antioxidant power among all flavonoids. Polyphenols are antioxidants that are helpful in reversing the problems caused by oxidative stress to the walls of arteries. Preliminary phytochemical analysis of extract was performed for following phytochemicals such as phenolics compounds, alkaloids, saponin, glycosides, phytosterols, tannin, flavonoids, steroids, terpenoids

\section{Experimental animals}

Healthy albino mice (20-25 g) of either sex were used for the experiment were procured from the animal house of Srinivas College of Pharmacy, Mangalore. They maintained under standard conditions (temperature $22 \pm 2{ }^{\circ} \mathrm{C}$, relative humidity $60 \pm 5 \%$ and $12 \mathrm{~h}$ light/dark cycle) and have free access to standard pellet diet and water ad libitum. The animals were housed in sanitized polypropylene cages containing sterile paddy husk as bedding. The Institutional Animal Ethics Committee reviewed and approved the experimental protocol

(Approval

no SCP/CPCSEA/F150/P11/2015).

\section{Passive Shock Avoidance Paradigm (PSAP) ${ }^{10}$}

Mice of either sex weighing between 20-25g will be divided into 5 groups of six animals each.

Group 1 : Animals serve as control and will receive only vehicle.

Group 2 : Animals will be administered Scopolamine, $(0.4 \mathrm{mg} / \mathrm{kg}$ i.p)

Group 3 : Animals will be treated with standard drug piracetam (400mg / kg i.p)

Group 4: Animals will be treated with low dose of FFJMDXMS $(1 \mathrm{ml} / \mathrm{kg})$ for 27 days orally.

Group 5: Animals will be treated with high dose of FFJMDXMS $(1.5 \mathrm{ml} / \mathrm{kg})$ for 27 days orally.

\section{Study chart}

From day 1-26 animals will be administered with drugs as mentioned above. On day 26 scopolamine $(0.4 \mathrm{mg} / \mathrm{kg}$ i.p) is administered to all animals (except group 1st ) 30 minute after the respective treatment, after 45 minute assessment of final SDL(step down latency) will be recorded.

\section{Procedure}

Passive avoidance behaviour based on negative reinforcement will be recorded to examine long-term memory. The apparatus consisted of a box $(27 \times 27 \times 27 \mathrm{~cm})$ having three walls of wood and one wall of Plexiglas, featuring a grid floor ( $3 \mathrm{~mm}$ stainless steel rods set $8 \mathrm{~mm}$ apart), with a wooden platform $(10 \times 7 \times 1.7 \mathrm{~cm})$ in the centre of the grid floor. The box will be illuminated with a $15 \mathrm{~W}$ bulb during the experimental period. Electric shock (20V AC) was delivered to the grid floor. Training will be carried out in two similar sessions. Each mouse will be gently placed on the wooden platform set in the centre of the grid floor. When the mouse stepped down and placed all its paws on the grid floor, shocks will be delivered for $15 \mathrm{sec}$ and the step-down latency (SDL) will be recorded. SDL is defined as the time taken by the mouse to step down from wooden platform to grid floor with its entire paw on the grid floor. Animals showing SDL in the range (215 sec) during the first test will be used for the second session and the retention test. The second session will be carried out 90 min after the first test. When the animals stepped down before $60 \mathrm{sec}$, electric shocks are delivered for $15 \mathrm{sec}$. During the second test, animals will be removed from shock free zone if they did not step down for a period of 60 sec. Retention will be tested after $24 \mathrm{~h}$ in a similar manner, except that the electric shocks will not be applied to the grid floor. Each mouse will be again placed on the platform, and the SDL was recorded with an upper cut-off time of 300 sec. 


\section{Morris Water Maze (MWM) ${ }^{11}$}

\section{Acquisition trials}

Each animal was subjected to four consecutive trials on each day with an interval of 5 min, during which mice was allowed to escape on the hidden platform and was allowed to remain there for $20 \mathrm{sec}$. In case of the inability of the animal to locate the hidden platform within $90 \mathrm{sec}$, it was gently guided by hand to the platform and allowed to remain there for $20 \mathrm{sec}$. Escape latency time (ELT) is the time taken by the animal to move from the starting quadrant to find the hidden platform in the target quadrant. In preliminary study, trial was conducted to familiarize the mice with the task and was not counted. Mice were subjected to acquisition trials for four consecutive days. Starting position on each day to conduct four acquisition trials was changed as follow:

Day 1: Q1 Q2 Q3 Q4

Day 2: Q2 Q3 Q4 Q1

Day 3: Q3 Q4 Q1 Q2

Day 4: Q4 Q1 Q2 Q3

\section{Retrieval trial}

On the next day, each mouse was allowed to explore the pool for 90s. Mean time spent of the animal in each of four quadrants was noted. The mean time spent by the mouse in target quadrant (Q4) for searching the hidden platform was noted as an index of retrieval. The experimenter always stood at the same position. Care was taken that relative location of water maze with respect to other objects in the laboratory, serving as prominent visual clues was not disturbed during the total duration of study.

\section{Treatment}

Mice of either sex weighing between (20-25g) were divided into 5 groups of six animals each.

Group 1: Animals serve as control and was receive only vehicle.

Group 2: Animals were administered Scopolamine on 19th and 27 th day $(0.4 \mathrm{mg} / \mathrm{kg}$ i.p.)

Group 3: Animals were treated with standard drug piracetam $(400 \mathrm{mg} / \mathrm{kg}$ i.p.)

Group 4: Animals were treated with low dose of FFJMDXMS $(1 \mathrm{ml} / \mathrm{kg})$ for 27 days orally.

Group 5: Animals will be treated with high dose of FFJMDXMS $(1.5 \mathrm{ml} / \mathrm{kg})$ for 27 days orally.

\section{Procedure}

From day 1-15 Animals were administered with drugs as mentioned above. On day 16, 17 and 18, animals were trained once daily on Morris water maze (MWM) and drug administration is continued. On day 19 , scopolamine $(0.4$ $\mathrm{mg} / \mathrm{kg}$ i.p.) is administered to all animals (except group I) $30 \mathrm{~min}$ after the respective treatment, After $45 \mathrm{~min}$ assessment of latency to find the platform was recorded by using MWM. The respective treatment with drug was continued for 1week. (Days 20-26). On day 27, scopolamine $0.4 \mathrm{mg} / \mathrm{kg}$ i.p. is injected to all the animals, 30 min prior to the last drug treatment. Assessment of learning and retention of memory was done after $45 \mathrm{~min}$ using MWM.

\section{Evaluation}

The latency to find the platform is measured as the time of placement of the mice in the water to the time it finds the platform. The time spent in target quadrant was also measured. If the animal fails to find the platform in any trial within $3 \mathrm{~min}$ it is placed on it for $10 \mathrm{~s}$.

\section{Estimation of Brain AChE activity ${ }^{12,13}$}

\section{Introduction}

The drugs approved for the AD therapy, act by counteracting the acetylcholine deficit that is they try to enhance the acetylcholine level in the brain. Acetylcholine is involved in the signal transfer in the synapses. After being delivered in the synapses, acetylcholine is hydrolyzed giving choline and acetyl group in a reaction catalyzed by the enzyme acetylcholinesterase. The molecular basis of the Alzheimer drugs used so far, take advantage of their action as acetylcholinesterase inhibitors.

\section{Collection of Brain Sample}

Immediately after behavioral testing (retrieval) on passive shock avoidance paradigm, animals were sacrificed by cervical dislocation under light anesthesia with diethyl ether. The whole brain was carefully removed from the skull. For preparation of brain homogenate, the fresh whole brain was weighed and transferred to a glass homogenizer and homogenized in an ice bath after adding 10 volumes of phosphate buffer $(\mathrm{pH} 8,0.1 \mathrm{M})$. The homogenate was centrifuged using refrigerated centrifuge at $3000 \mathrm{rpm}$ for $10 \mathrm{~min}$ at $4^{\circ} \mathrm{C}$ and the resultant cloudy supernatant liquid was used for the estimation of brain acetylcholinesterase activity.

\section{Procedure}

Brain acetylcholinesterase was estimated by using Elman method. Briefly, $0.4 \mathrm{~mL}$ of brain homogenate was added to a test tube containing $2.6 \mathrm{~mL}$ of phosphate buffer. $0.1 \mathrm{~mL}$ DTNB reagent was added to the above mixture and absorbance was noted at $412 \mathrm{~nm} .0 .02 \mathrm{~mL}$ of acetylcholine iodide solution was added and again absorbance was noted $15 \mathrm{~min}$ thereafter. The end point is the formation of the yellow color because of the reaction of thiocholine with dithiobisnitrobenzoate ions. Change in absorbance per min was calculated. The AchE activity is measured by using an artificial substrate Acetyl thiocholine (ATC). AchE acts on ATC and release thiocholine and acetic acid. Thiocholine further is allowed to react with $-\mathrm{SH}$ reagent 5,5-dithio-bis- (2, nitro benzoic acid) (DTNB) which is reduced to thionitro benzoic acid, a yellow-coloured anion 
with absorption maxima $412 \mathrm{~nm}$. The molar extinction coefficient of thionitro benzoic acid is $1.36 \times 10$ $4 / \mathrm{molar} / \mathrm{cm}$. The concentration of thionitro benzoic acid is determined using Shimadzu UV-1700 Pharmacspec UV-Vis spectrophotometer which is directly proportional to AchE activity. The rate of the reaction was calculated using following formula.

$\mathrm{R}=\delta O D \times$ volume of assay $(3 \mathrm{ml}) / \mathrm{E} \times \mathrm{mg}$ of protein

Where $R$ is the rate of enzyme activity in ' $n$ ' mole of acetylcholine iodide hydrolyzed per minute per $\mathrm{mg}$ of protein. $\delta O D$ is the change in absorbance per minute and $E$ is the extinction coefficient, which is $13600 \mathrm{M}-1 \mathrm{~cm}-1$.

\section{Statistical analysis}

All data were expressed as Mean \pm SEM. The statistical significance between groups were compared using one way ANOVA, followed by Dunnett's (multiple comparison test).

\section{RESULTS}

\section{Preliminary phytochemical screening of FFJMDxMS}

Preliminary phytochemical analysis was performed and the results confirm the presence of Alkaloids, Glycosides, Phytopherols, Flavonoids, Saponins, Tannins and Carbohydrates.

\section{Passive shock avoidance paradigm (PSAP)}

The results of PSAP in mice after administration of FFJMDxMS are given in (Table no.1). On day 16, 17 and 18, animals were trained once daily on PSAP and drug administration was continued. In PSAP model the SDL of mice was noted on 19th day (learning) and after 24 hours i.e on 20th day (retension).

In the group treated with control, the onset time for 19th and 20th day, the step-down latency (SDL) were found to be $113.6 \pm 0.10$ and $114.5 \pm 0.10$ seconds, respectively. FFJMDxMS at lower dose $(1 \mathrm{ml} / \mathrm{kg})$ significantly $(P<0.01)$ decrease in SDL for 19th and 20th day.

On 27th day (learning) and after 24 hours i.e on 28th day (retension) SDL was noted. In the group treated with control, the onset time for 27th and 28th day, the stepdown latency (SDL) were found to be $115.3 \pm 0.13$ and $117.6 \pm 0.10$ seconds respectively. FFJMDxMS at lower dose $(1 \mathrm{ml} / \mathrm{kg})$ significantly $(P<0.05)$ decreased SDL for 27 th and 28 th day. Higher dose of FFJMDxMS $(1.5 \mathrm{ml} / \mathrm{kg})$ produced significant $(P<0.01)$ decrease in SDL for 27th and 28th day.

Thus, all the two doses of FFJMDxMS produced significant reduction in SDL. Hence it shows activity against scopolamine induced amnesia. Thus, it can be concluded that it shows memory enhancing activity against scopolamine induced Alzheimer's Disease.

Table 1: Effect of FFJMDxMS on PSAP task on 19th and 27th day

\begin{tabular}{|c|c|c|c|c|c|}
\hline $\begin{array}{l}\text { Group } \\
\text { No. }\end{array}$ & Treatment & $\begin{array}{l}\text { On 19th day } \\
\text { SDL (sec) }\end{array}$ & After $24 \mathrm{hrs}$ & $\begin{array}{l}\text { On 27th day SDL } \\
\text { (sec) }\end{array}$ & After $24 \mathrm{hrs}$ \\
\hline $\mathbf{I}$ & Control & $132.6 \pm 1.10$ & $134.5 \pm 1.15$ & $135.3 \pm 1.11$ & $136.6 \pm 1.12$ \\
\hline II & Scopolamine $0.4 \mathrm{mg} / \mathrm{kg}$ & $83.9 \pm 1.10$ & $85.50 \pm 0.12$ & $86.62 \pm 0.10$ & $87.40 \pm 2.11$ \\
\hline III & $\begin{array}{l}\text { Scopolamine } 0.4 \mathrm{mg} / \mathrm{kg} \\
\text { +Piracetam } 400 \mathrm{mg} / \mathrm{kg}\end{array}$ & $125.6 \pm 0.96 * * *$ & $\begin{array}{c}127.5 \pm \\
1.10 * * *\end{array}$ & $\begin{array}{c}128.5 \pm \\
1.11^{* * *}\end{array}$ & $129.5 \pm 0.99 * * *$ \\
\hline IV & $\begin{array}{l}\text { Scopolamine } 0.4 \mathrm{mg} / \mathrm{kg}+ \\
\text { FFJMDxMS } 1 \mathrm{ml} / \mathrm{kg}\end{array}$ & $113.7 \pm 0.711 * *$ & $\begin{array}{l}114.6 \pm \\
0.89 * *\end{array}$ & $\begin{array}{l}115.6 \pm \\
0.9^{* *}\end{array}$ & $116.6 \pm 0.89 * *$ \\
\hline $\mathbf{v}$ & $\begin{array}{l}\text { Scopolamine } 0.4 \mathrm{mg} / \mathrm{kg}+ \\
\text { FFJMDXMS } 1.5 \mathrm{ml} / \mathrm{kg}\end{array}$ & $115.7 \pm 0.80 * *$ & $\begin{array}{l}116.6 \pm \\
1.12 * *\end{array}$ & $\begin{array}{l}117.6 \pm \\
0.9 * *\end{array}$ & $118.6 \pm 1.53^{* *}$ \\
\hline
\end{tabular}

Values are expressed as Mean $\pm \mathrm{SEM} ; \mathrm{n}=6$; ${ }^{* *} \mathrm{P}<0.01 * * * \mathrm{P}<0.001$ compared to scopolamine group. (ANOVA followed by Dunnett's multiple comparison test) FFJMDxMS: Fresh fruit juice of (HYBRID PERENTAGE)-malus domestica $x$ malus sylvestris.

\section{Morris water maze}

The results of MWM in mice after administration of FFJMDxMS are given in (Table no.2). On day 16, 17 and 18, animals were trained once daily on Morris water maze (MWM) and drug administration is continued. In the group treated with control, the onset time for 19th and 20th day, the escape latency (ELT) were found to be $27.54 \pm 0.315$ and $25.66 \pm 0.631$ seconds respectively. FFJMDxMS at lower dose $(1 \mathrm{ml} / \mathrm{kg})$ significantly $(\mathrm{P}<0.05)$ reduced and at higher dose $(1.5 \mathrm{ml} / \mathrm{kg})$ produced significant $(P<0.01)$ decrease in ELT for both 19th and 20th day.

The TSTQ time is noted on 19th and 20th day. FFJMDxMS at lower dose $(1 \mathrm{ml} / \mathrm{kg})$ significantly $(P<0.05)$ increased and at higher dose $(1.5 \mathrm{ml} / \mathrm{kg})$ produced significant $(P<0.01)$ increase in TSTQ. Thus, all the two doses of FFJMDXMS produced significant reduction in ELT and significant increase in TSTQ. Hence it shows activity against scopolamine induced amnesia. Thus, it can be concluded that it shows learning and memory enhancing activity. 
Table 2: Effect of FFJMDxMS on escape latency and TSTQ of young mice by MWM (learning \& memory) on 19th day

\begin{tabular}{|c|c|c|c|c|c|}
\hline $\begin{array}{c}\text { Group } \\
\text { No. }\end{array}$ & Treatment & $\begin{array}{c}\text { On 19th day ELT } \\
\text { (sec) }\end{array}$ & $\begin{array}{c}\text { ELT (sec) After } \\
\mathbf{2 4} \text { hrs ( 20th } \\
\text { day) }\end{array}$ & $\begin{array}{c}\text { On 19th day TSQT } \\
\text { (sec) }\end{array}$ & $\begin{array}{c}\text { After 24 hrs (20th } \\
\text { day) TSQT (sec) }\end{array}$ \\
\hline $\mathbf{I}$ & Control & $27.34 \pm 0.105$ & $25.66 \pm 0.11$ & $24.69 \pm 0.09$ & $25.27 \pm 0.096$ \\
\hline II & Scopolamine $0.4 \mathrm{mg} / \mathrm{kg}$ & $46.45 \pm 0.14$ & $45.55 \pm 0.11$ & $13.54 \pm 0.11$ & $12.62 \pm 0.12$ \\
\hline III & $\begin{array}{c}\text { Scopolamine } 0.4 \mathrm{mg} / \mathrm{kg} \\
\text { +Piracetam } 400 \mathrm{mg} / \mathrm{kg}\end{array}$ & $34.62 \pm 0.125^{* * *}$ & $32.67 \pm 0.99 * * *$ & $18.55 \pm 0.10^{* * *}$ & $19.58 \pm 0.07 * * *$ \\
\hline $\mathbf{I V}$ & $\begin{array}{c}\text { Scopolamine } 0.4 \mathrm{mg} / \mathrm{kg}+ \\
\text { FFJMDxMS } 1 \mathrm{ml} / \mathrm{kg}\end{array}$ & $38.64 \pm 0.116^{* *}$ & $37.59 \pm 0.09 * *$ & $14.58 \pm 0.34^{* *}$ & $15.56 \pm 0.10^{* *}$ \\
\hline $\mathbf{V}$ & $\begin{array}{c}\text { Scopolamine } 0.4 \mathrm{mg} / \mathrm{kg}+ \\
\text { FFJMDxMS } 1.5 \mathrm{ml} / \mathrm{kg}\end{array}$ & $36.41 \pm 0.07 * *$ & $34.5 \pm 0.090^{* *}$ & $16.56 \pm 0.10^{* *}$ & $17.61 \pm 0.080^{* *}$ \\
\hline
\end{tabular}

Values are expressed as Mean $\pm \mathrm{SEM} ; \mathrm{n}=6 ; * * \mathrm{P}<0.01 * * * \mathrm{P}<0.001$ compared to scopolamine group. (ANOVA followed by Dunnett's multiple comparison test) FFJMDxMS.

Table 3: Effect of FFJMDxMS on escape latency and TSTQ of young mice by MWM (learning \& memory) on 27th day

\begin{tabular}{|c|c|c|c|c|c|}
\hline $\begin{array}{l}\text { Group } \\
\text { No. }\end{array}$ & Treatment & $\begin{array}{c}\text { On 27th day ELT } \\
\text { (sec) }\end{array}$ & $\begin{array}{c}\text { ELT (sec) After } 24 \\
\text { hrs ( 28th day) }\end{array}$ & $\begin{array}{l}\text { On 17th day TSQT } \\
\text { (sec) }\end{array}$ & $\begin{array}{l}\text { After } 24 \text { hrs (28th } \\
\text { day) TSQT (sec) }\end{array}$ \\
\hline $\mathbf{I}$ & Control & $24.49 \pm 0.096$ & $23.58 \pm 0.096$ & $26.54 \pm 0.10$ & $28.58 \pm 0.11$ \\
\hline II & Scopolamine 0.4 mg/kg & $44.56 \pm 0.11$ & $42.58 \pm 0.10$ & $11.58 \pm 0.10$ & $10.61 \pm 0.08$ \\
\hline III & $\begin{array}{l}\text { Scopolamine } 0.4 \text { mg } / \mathrm{kg} \\
\text { +Piracetam } 400 \mathrm{mg} / \mathrm{kg}\end{array}$ & $30.60 \pm 0.094 * * *$ & $28.65 \pm 0.093^{* * *}$ & $22.66 \pm 0.10 * * *$ & $23.59 \pm 0.09 * * *$ \\
\hline IV & $\begin{array}{l}\text { Scopolamine } 0.4 \mathrm{mg} / \mathrm{kg}+ \\
\text { FFJMDXMS } 1 \mathrm{ml} / \mathrm{kg}\end{array}$ & $35.56 \pm 0.086 * *$ & $33.58 \pm 0.097 * *$ & $20.63 \pm 0.11^{* *}$ & $21.47 \pm 0.07 * *$ \\
\hline $\mathbf{v}$ & $\begin{array}{c}\text { Scopolamine } 0.4 \mathrm{mg} / \mathrm{kg}+ \\
\text { FFJMDxMS } 1.5 \mathrm{ml} / \mathrm{kg}\end{array}$ & $33.49 \pm 0.098^{* *}$ & $30.51 \pm 0.080^{* *}$ & $23.63 \pm 0.108 * *$ & $24.71 \pm 0.07 * *$ \\
\hline
\end{tabular}

Values are expressed as Mean $\pm \mathrm{SEM} ; \mathrm{n}=6$; ** $\mathrm{P}<0.01 * * * \mathrm{P}<0.001$ compared to scopolamine group. (ANOVA followed by Dunnett's multiple comparison test) FFJMDxMS.

On 27th and 28th day, the escape latency (ELT) of control group was found to be $24.49 \pm 0.537$ and $23.62 \pm 0.780$ seconds respectively. FFJMDxMS at lower dose $(1 \mathrm{ml} / \mathrm{kg})$ significantly $(\mathrm{P}<0.05)$ reduced and at higher dose $(1.5 \mathrm{ml} / \mathrm{kg})$ produced significant $(P<0.01)$ decrease in ELT for both 27th and 28th day. The TSTQ time is noted on 27th and 28th day. FFJMDxMS at lower dose $(1 \mathrm{ml} / \mathrm{kg})$ significantly $(P<0.01)$ decrease in ELT for both 27th and 28th day. The TSTQ time is noted on 27th and 28th day. FFJMDxMS at lower dose $(1 \mathrm{ml} / \mathrm{kg})$ significantly $(P<0.05)$ increased and at higher dose $(1.5 \mathrm{ml} / \mathrm{kg})$ produced significant $(P<0.01)$ increase in TSTQ. Thus, all the two doses of FFJMDxMS produced significant reduction in ELT and significant increase in TSTQ. Hence it shows activity against scopolamine induced amnesia. Thus, it can be concluded that it shows learning and memory enhancing activity.

\section{Estimation of brain AchE activity}

The results and the statistical analysis for the changes in acetylcholine esterase (AchE) concentration in isolated mice's whole brain homogenate after administration of ALEB are given in (Table no.4). In the control group (Group I) animals the levels of AchE in the brain was found to be $28.58 \pm 0.093$. Scopolamine administration was found to significantly $(p<0.001)$ increase the levels of AchE in the brain of negative control group (Group II) animals as compared to control group (Group I) animals. Treatment with FFJMDxMS $(1 \mathrm{ml} / \mathrm{kg})$ significantly $(p<0.01)$ reduced the level of AchE in the brain of (Group V) animals as compared to the scopolamine treated group. Treatment with the standard drug, piracetam (400 mg/kg, i.p.) in (Group II) animals showed non-significant.

Table 4: Effect of FFJMDxMS on Acetylcholine esterase (AChE) activity

\begin{tabular}{|c|c|c|}
\hline Group no. & Treatment & AChE activity ( $\mu \mathrm{mol}$ ) \\
\hline $\mathbf{I}$ & Control & $25.58 \pm 0.093$ \\
\hline II & $\begin{array}{l}\text { Scopolamine } 0.4 \\
\mathrm{mg} / \mathrm{kg}\end{array}$ & $30.58 \pm 0.103$ \\
\hline III & Piracetam 400 mg/kg & $18.62 \pm 0.10 * * *$ \\
\hline IV & $\begin{array}{l}\text { FFJMDxMS low dose } \\
1 \mathrm{ml} / \mathrm{kg}\end{array}$ & $23.68 \pm 0.097 * *$ \\
\hline v & $\begin{array}{c}\text { FFJMDxMS high dose } \\
1.5 \mathrm{ml} / \mathrm{kg}\end{array}$ & $21.59 \pm 0.095 * *$ \\
\hline
\end{tabular}

Values are expressed as Mean \pm SEM, $\mathrm{n}=6 ; * * \mathrm{P}<0.01$ $* * * \mathrm{P}<0.001$ ns-non significant (ANOVA followed by Dunnett's multiple comparison tests) FFJMDxMS. 


\section{DISCUSSION}

Learning is often defined as a relatively lasting change in behavior that is the result of experience. Memory is an organism's ability to store, retain, and recall information. Learning and memory together called as cognition. Alzheimer's disease is a progressive neurologic disease that results in the irreversible loss of neurons, particularly in the cortex and hippocampus. ${ }^{14}$ The disease process is associated with plaques and neurofibrillary tangles in the brain. In the present study, the effect of improving memory scopolamine induced AD type amnesia in mice. Both long term and short-term memory deficit are produced by scopolamine. Similarities have been observed between patient with Alzheimer's disease and scopolamine treated animals. The cognitive enhancing activity of FFJMDXMS on scopolamine induced Alzheimer's Disease in mice was investigated by using two models Passive shock avoidance paradigm and Morris water maze. On day 16, 17 and 18 animals were trained once daily on both models and drug administration was continued.

In PSAP model the assessment of learning done by recording step-down latency. ${ }^{15}$ On 19th day after administration of drug the significant decrease in SDL of mice was noted (learning) and similar procedure is followed to check memory after 24 hours i.e 20th day (retension). The significant reduction in SDL value indicated improvement in memory. Out of the two effective doses of FFJMDXMS ( 1 and $1.5 \mathrm{ml} / \mathrm{kg}$,) the longterm administration of higher dose $(1.5 \mathrm{ml} / \mathrm{kg})$ produced better memory enhancing effect in mice $(P<0.01)$ as compared to the lower dose $(P<0.05)$ in PSAP model.

Morris water maze is used to assess learning and memory in experimental mice During the acquisition trials the animal learns to locate a hidden platform and subsequently develops spatial memory. Normal animals have been reported to show a gradual decrease in escape latency (ELT) in Morris water maze during the acquisition period, which is an indication of learning. This effect proved that scopolamine impairs the retrieval of memory or produces retrograde amnesia. ${ }^{16}$ Similarly in the present study on 27th day scopolamine was injected to animal's 30 mins prior to the last drug treatment and assessment of learning on 27th day and retention of memory is checked after 24 hours i.e on 28th day. Similarly, the TSTQ was recoded on 27 th and 28 th day.

The significant reduction in ELT value and increase in TSTQ indicated improvement of learning and memory in MWM model. Out of the two effective doses of FFJMDXMS ( 1 and $1.5 \mathrm{ml} / \mathrm{kg}$ ) the long-term administration of higher dose $(1.5$ $\mathrm{ml} / \mathrm{kg}$ ) produced better memory enhancing effect in mice $(P<0.01)$ as compared to the lower dose $(P<0.05)$ in MWM model hence the higher dose was employed for elucidating the probable mechanisms of memory enhancing activity. On 28th day after administration of drug and participating in test trail the animals were sacrificed by cervical dislocation under light anesthesia with diethyl ether and brain was collected and homogenate was centrifuged and the resultant cloudy supernatant liquid was used for the estimation of brain acetylcholinesterase activity. ${ }^{17}$ The whole brain AChE activity was measured on the basis of the formation of yellow color due to the reaction of thiocholine with dithiobisnitrobenzoate ions.

In the present study, we found that FFJMDXMS decreases acetylcholine esterase activity in brain homogenate. As a result, there is accumulation of acetyl choline in brain (hippocampal region in cortex), hence triggering of cholinergic firings, thereby enhanced memory and cognition. As found in this study, FFJMDXMS at higher dose $(1.5 \mathrm{ml} / \mathrm{kg})$ showed better result compared to lower dose which facilitates retention of learned task, therefore it may be considered as potential AChE inhibitor or anticholinesterase agent found to significantly $(p<0.01)$ reduce the activity of AchE in the brain. By applying the knowledge on various research carried out in the area of nootropic several mechanism in the form of hypothesis can be proposed to justify the activity of FFJMDXMS in experimental models, various phytochemical studies showed presence of flavonoids epicatechin, quercetin and catechins are the active constituents. It also has highest levels of vitamins, and polyphenols. Recent studies highlighted the role of polyphenols in memory. Study shown that polyphenols may improves the cerebral circulation and brain metabolism which is a key factor in improvement of memory.

\section{CONCLUSION}

In the present study FFJMDXMS showed memory enhancing activity in mice probably by inhibiting brain acetylcholinesterase activity, due to its antioxidant activity. The study proves the modern claims of FFJMDXMS being a very good remedy for preventing Alzheimer's disease. It is worth for further investigations for isolation of more bioactive molecules for the treatment and using more experimental paradigms are required for further confirmation of nootropic potential of Green apple in the treatment of various cognitive disorders.

\section{REFERENCES}

1. Prakash K, Usha D, Goyal VC, Assistive and enabling technology needs of elderly people in India, Issues and initial results. Assistive technologies-towards home-based elder care, 2009; 10(6): 211-19.

2. Shyamal K, Sandip pal, Malay K Ghosal, Dementia Indian scenario, Neural India, 2012; 60(6): 618-24.

3. Kwon SH, Lee HK, Kim JA, Hong $\mathrm{SI}$, Kim HC, Jo TH, et al, Neuroprotective effects of chlorogenic acid on scopolamineinduced amnesia via antiacetylcholinesterase and antioxidative activities in mice. Europian Journal Pharmacology, 2010; 64(9): 210-17

4. Ferri $\mathrm{CP}$, Prince $\mathrm{M}$, Brayne $\mathrm{C}$, Brodaty $\mathrm{H}$, Fratiglioni L, Ganguli $M$, et al, Global prevalence of dementia: a Delphi consensus study, Lancet, 2005; 36(6): 2112-27. 
5. Yadav KD, Reddy KR, Kumar V. Encouraging effect of Brahmi Ghrita in amnesia, International Journal of Green Pharmacy, 2013; 7(2): 122-6.

6. Factor I, Bhaskar M, Chintamaneni M, Investigating the role of Eclipta alba on brain antioxidant markers, cognitive performance and acetylcholinesterase activity of rats, International Journal of Pharmacology and Phytopharmacoly Res.2014; 3: 390-4.

7. Hwang J, Hwang $\mathrm{H}$, Lee HW, Suk K, Microglia signaling as a target of donepezil. Neuropharmacology,2010; 5(8): 11229.

8. J. Dixon: E.W. Hewett, Temperature affects postharvest colour changes of apple, Palmerston, New Zealand: Massey University, 1998; 2(2): 211-9.

9. Eberhardt $\mathrm{M}$, Lee $\mathrm{C}$, Liu RH, Antioxidant activity of fresh apples, Nature, 2000; 40(5): 903-90.

10. Satish S, Rajarajeshwari N, Narayana swamy VB, Studies on Therapeutic Potential of Oil of Cymbopogon Citratus in Treatment of Alzheimer's Disease, 2013; 5(1): 2027-36

11. Meera $S$, Mamatha $K$, Assessment of learning and memory enhancing Activity of phoenix dactylifera (date) in rats, World Journal of Pharmaceutical Research, 2014; 3(10): 1215-25.
12. Gerhard VH, Drug discovery and evaluation pharmacological assays, 2nd edition. Germany Springer-Verlag Berlin Heidelberg publishers, 2002; 2( 64): 435-6.

13. McKhann G, Drachman D, Folstein M, Katzman R, Price D, Stadlan EM, Clinical diagnosis of Alzheimer's disease: report of the NINCDS-ADRDA Work Group under the auspices of Department of Health and Human Services Task Force on Alzheimer's Disease, Neurology,1984; 34(1): 939-44.

14. Ballard C, Gauthier S, Corbett A, Brayne C, Aarsland D, Jones E, Alzheimer's disease, Lancet, 2011; 377(1): 10132-39.

15. Joshi $H$, Parle $M$, Zingiber officinale: evaulation of its nootropic effect in mice, African Journal of Traditional, Complementary and Alternative Medicines, 2006 Jan 12; 3(1): 64-74.

16. Gacar N, Mutlu O, Utkan T, Celikyurt IK, Gocmez SS, Ulak G, Beneficial effects of resveratrol on scopolamine but not mecamylamine induced memory impairment in the passive avoidance and Morris water maze tests in rats, Pharmacology Biochemistry and Behavior, 2011 Sep 1; 99(3): 316-23.

17. Biradar SM, Joshi H, Chheda TK, Biochanin-A ameliorates behavioural and neurochemical derangements in cognitivedeficit mice for the betterment of Alzheimer's disease, Human \& experimental toxicology, 2014 Apr; 33(4): 369-82.

Source of Support: None declared.

Conflict of Interest: None declared.

For any question relates to this article, please reach us at: editor@globalresearchonline.net New manuscripts for publication can be submitted at: submit@globalresearchonline.net and submit_ijpsrr@rediffmail.com 